\title{
Validation of prognostic scoring systems for predicting 30-day mortality in perforated peptic ulcer disease
}

\author{
Shaili Patel (iD), Devanshu Kalra (ID), Samir Kacheriwala (iD), Mihir Shah (ID), Dipesh Duttaroy (ID) \\ Department of Surgery, Medical College Baroda and Sir Sayajirao General Hospital, Vadodara, India
}

\begin{abstract}
Objective: Perforations in Peptic Ulcer Disease are known to cause considerable morbidity and mortality. The objective of this study was to compare efficacy of known clinical parameters and three existing scoring systems in predicting 30-day mortality and determining mortality risk stratification based on risk factors.

Material and Methods: This was a prospective observational study of 190 patients operated for perforated peptic ulcer over a period of 14 months at a 1500 bed tertiary care university hospital in Western India.

Results: The mortality rate observed was $18.95 \%$. Elderly population, raised serum creatinine, time delay to surgery $>24$ hours, preoperative shock and pre-existing medical illness were identified as risk factors for poor postoperative prognosis. The Area under curve for mortality prediction was 0.590 for ASA, 0.745 for Boey and 0.804 for PULP score. Mortality was best anticipated by a combination of raised serum creatinine levels, preoperative shock and delayed surgery by multivariate logistic regression analysis.

Conclusion: Poor outcome was significantly higher in the elderly, patients with raised serum creatinine, preoperative shock, pre-existing medical illness and when the time delay to surgery was $>24$ hours. In spite of the Boey score being more practical in application, PULP score proved to be a more precise indicator of mortality. A larger study inclusive of other Mortality Risk Prediction Models would help formulate a more accurate and population specific scoring system.
\end{abstract}

Keywords: Perforated peptic ulcer, scoring systems, risk factors, 30-day mortality

Cite this article as: Patel S, Kalra D, Kacheriwala S, Shah M, Duttaroy D. Validation of prognostic scoring systems for predicting 30-day mortality in perforated peptic ulcer disease. Turk J Surg 2019; 35 (4): 252-258.

\section{Corresponding Author} Samir Kacheriwala

E-mail: dr_samir_k@yahoo.com

Received: 27.05.2018

Accepted: 17.10 .2018

Available Online Date: 16.12 .2019

O Copyright 2019 by Turkish Surgical Society Available online at www.turkjsurg.com

DOI: $10.5578 /$ turkjsurg.4211

\section{INTRODUCTION}

Perforated peptic ulcer disease (PUD) is potentially fatal unless treated surgically (1). Although the prevalence of peptic ulcer in the general population is not known, American Gastroenterology Association (AGA) has reported a 10-12\% prevalence in patients with upper gastrointestinal symptoms $(2,3)$. Among all the complications relating to peptic ulcer disease, perforation is the most dreaded since it has the highest mortality rate (4). Population based studies have reported mortality rates of 25-30\% following perforated peptic ulcer (PPU) $(5,6)$.

The pathogenesis of PPU is multifactorial and results from an interaction between environmental, microbiological-Helicobacter pylori, pharmacological-Non Steroidal Anti-Inflammatory Drugs (NSAIDs) and steroids and genetic factors $(7,8)$. Recognizing individual clinical parameters indicating higher risk of fatality and classifying patients according to low or high risk pre-operatively can help with optimization of care and resource allocation (9). Various risk prediction models like American Society of Anaesthesiologists (ASA) physical status, Boey and Peptic Ulcer Perforation Score (PULP) have been devised for that. Due to geographic and demographic variations, it becomes prudent to validate each existing model and test its diagnostic efficacy for a particular scenario. An ideal scoring system should be easy to apply, include all pre-operative variables proven to affect outcomes, highly sensitive and specific and should not cause additional fiscal or organizational burden (9). The present study was conducted to compare efficacy of ASA, Boeyand PULP score in predicting 30-day mortality in patients with PPU based on clinical parameters, to determine mortality risk stratification and calculate incidence of 30-day mortality after surgical intervention for PPU at our institution. 


\section{MATERIAL and METHODS}

\section{Patients and Setting}

A prospective observational study was conducted the General Surgical Department of a 1500 bed tertiary care Medical Collage Baroda and Sir Sayajirao General Hospital in Western India over a period of 14 months from September 2015 to October 2016, after obtaining prior approval of the institutional ethics committee. Out of the 204 patients operated for PPU, 190 patients were evaluated, 14 were excluded due to incomplete data. Informed consent was obtained from all patients. All consenting patients above the age of 18 years diagnosed and operated for benign gastric or duodenal ulcer were included. Patients with malignant perforated ulcer, those conservatively treated for PPU and patients who expired before any surgical intervention were excluded.

PPU was diagnosed based on clinical features, laboratory tests, plain abdominal skiagram and intraoperative findings. Patients were evaluated for past history of dyspepsia and epigastric pain, long term NSAIDs or steroid ingestion, smoking and alcohol consumption, pre-existing co-morbidities including stroke, diabetes mellitus, tuberculosis, respiratory, cardiovascular, renal or liver disease. All cases were managed by surgical procedure involving open primary closure of perforation by interrupted 2-0 Polyglactin 910 sutures covered with pedicle omentoplasty.

\section{Data Studied}

Factors affecting patient outcome like age and gender, long term NSAIDs/steroid intake, renal function, preoperative shock and hydration (systolic blood pressure $<100 \mathrm{mmHg}$ and heart rate $>100$ beats/min), preoperative co-morbidities and time delay from admission to surgery were recorded. All patients were scored under three PPU scoring systems: ASA, Boey and PULP. Patients were grouped for age $\leq 60$ or $>60$ years, sex, NSAIDs or steroid intake, serum creatinine $\leq 1.47$ or $>1.47 \mathrm{mg} / \mathrm{dL}$, co morbidities present or absent, time delay $\leq 24 \mathrm{hr}$ or $>24 \mathrm{hr}$, ASA class $\leq 3$ or $>3$, Boey score $\leq 1$ or $>1$ and PULP score $\leq 7$ or $>7$.

Outcome was assessed by mortality within 30-days of surgery for each group. The diagnostic abilitiesof three PPU scoring systems in the form of sensitivity, specificity, positive predictive value and negative predictive valuewere calculated.

\section{Statistical Tests and Statistical Analysis}

Data was analyzed using MedCalc Statistical Software version 18 (MedCalc Software bvba, Ostend, Belgium; http://www.medcalc.org; 2018). Mean and standard deviation for continuous data, and number and percentage for categorical variables were calculated. Pearson's Chi Square or Fisher's exact test was used for categorical data. All tests were 2-tailed with $p<0.05$ considered significant. Odds ratio for mortality was calculated for age, sex, serum creatinine, use of steroids and NSAIDS, preoperative shock, pre-existing co-morbidities, delay in surgery and individual PPU scores to check for their association.
Univariate analysis was done for pre-operative factors affecting patient outcome, ASA score, Boey score and PULP score to check for their association with the mortality. Results of these analyses were used in Logistic regression analysis for dichotomous outcome like mortality. To assess if the regression models' estimates fit the data, "Goodness of Fit" Chi Square test and Hosmer- Lemeshow test were used. Receiver Operating Characteristics (ROC) Analysis and Area Under Curve (AUC) was calculated for the individual scores and compared. An AUC value $>0.8$ was considered good, between 0.60-0.80 was considered as moderate, and < 0.60 was regarded poor.

\section{RESULTS}

Of the 190 operated patients, 36 (18.95\%) expired within 30-days of surgery.

\section{Patient Profile and Preoperative Clinical Parameters}

Patient demographic profiles, pre-operative parameters and their odds ratio for mortality are depicted in Table 1. Mean age of patients was $42.42 \pm 16.34$ years. Male to female ratio was noted to be 3.63:1. The most commonly observed pre-operative co morbidity was COPD (50\%), followed by cirrhosis (26.47\%). Five out of 34 patients had multiple coexistent co morbidities. The time delay defined as surgical delay more than 24 hours since admission ranged from 26 to 52 hours.

\section{Risk Assessment Scores and their ROC curves}

Majority of the patients belonged to ASA physical class $4(n=149$, $78.42 \%)$, followed by ASA physical class $3(n=33,17.37 \%)$ and ASA physical class $5(n=8,4.21 \%)$. None of the patients could be classified under class 1 or 2.157 patients belonged to class 4 or 5 . Patients categorized to Boey class 0 were 106 (55.79\%), Boey class 1 were 54 (28.42\%), Boey class 2 were 28 (14.73\%) and 2 (01.05\%) belonged to Boey class 3. Maximum number of patients ( $n=82$, 43.16\%) had a PULP score of 5. Patients having PULP score of 6, 7 and 8 were 21 (11.05\%), 24 (12.63\%) and 22 (11.58\%) respectively. In PULP score category 3 and 9, 13 (06.84\%) and 12 (06.32\%) patients were noted. There were none noted with any other score.

The odds ratios (OR) of risk assessment scores for mortality are enlisted in Table 1. Receiver operating characteristic (ROC) curve analysis andArea under curve (AUC) for the three scoring systems are shown in Table 2 and Figure 1.

\section{Regression Analysis}

Logistic regression analysis for pre-operative parameters showed significant association of mortality with raised serum creatinine levels, preoperative shock and delayed surgery. Age and preoperative comorbidities were not included in the calculations because of insignificant association with mortality in univariate analysis. Boey and PULP scores when subjected to logistic regression analysis revealed their significant association with mortality (Table 3). ASA score was left out of the regression model 
Table 1. Patient characteristics, pre-operative clinical parameters and Odds Ratio for mortality for each univariate factor

\begin{tabular}{|c|c|c|c|c|}
\hline Variable & Mean \pm SD or Percentage (\%) & Number (n) & Odds Ratio for Mortality & p \\
\hline $\begin{array}{l}\text { Age } \\
\qquad \begin{array}{l}\leq 60 \text { years } \\
>60 \text { years }\end{array}\end{array}$ & $42.42 \pm 16.34$ years & $\begin{array}{c}162 \\
28\end{array}$ & $\begin{array}{c}1 \\
1.914(0.766-4.782)\end{array}$ & 0.165 \\
\hline $\begin{array}{l}\text { Gender } \\
\text { Female } \\
\text { Male }\end{array}$ & $\begin{array}{l}21.58 \% \\
78.42 \%\end{array}$ & $\begin{array}{c}41 \\
149\end{array}$ & $\begin{array}{c}1 \\
1.174(0.473-2.913)\end{array}$ & 0.729 \\
\hline $\begin{array}{l}\text { Steroid intake } \\
\text { No } \\
\text { Yes }\end{array}$ & $\begin{array}{l}95.26 \% \\
4.74 \%\end{array}$ & $\begin{array}{c}181 \\
9\end{array}$ & $\begin{array}{c}1 \\
1.235(0.246-6.212)\end{array}$ & 0.798 \\
\hline $\begin{array}{l}\text { NSAIDs intake } \\
\text { No } \\
\text { Yes }\end{array}$ & $\begin{array}{l}91.05 \% \\
8.95 \%\end{array}$ & $\begin{array}{c}173 \\
17\end{array}$ & $\begin{array}{c}1 \\
0.909(0.247-3.347)\end{array}$ & 0.886 \\
\hline $\begin{array}{l}\text { Serum creatinine level } \\
\quad \leq 1.47 \mathrm{mg} / \mathrm{dL} \\
\quad>1.47 \mathrm{mg} / \mathrm{dL}\end{array}$ & $\begin{array}{l}68.95 \% \\
31.05 \%\end{array}$ & $\begin{array}{c}131 \\
59\end{array}$ & $\begin{array}{c}1 \\
17.124(6.847-42.826)\end{array}$ & $<0.0001$ \\
\hline $\begin{array}{l}\text { Preoperative shock } \\
\text { No } \\
\text { Yes }\end{array}$ & $\begin{array}{l}86.32 \% \\
13.68 \%\end{array}$ & $\begin{array}{c}164 \\
26\end{array}$ & $\begin{array}{c}1 \\
9.286(3.765-22.904)\end{array}$ & $<0.0001$ \\
\hline $\begin{array}{l}\text { Preoperative comorbidities } \\
\text { No } \\
\text { Yes }\end{array}$ & $\begin{array}{l}82.11 \% \\
17.89 \%\end{array}$ & $\begin{array}{c}156 \\
34\end{array}$ & $\begin{array}{c}1 \\
3.000(1.312-6.859)\end{array}$ & 0.009 \\
\hline $\begin{array}{l}\text { Delay in surgery } \\
\text { No } \\
\text { Yes }\end{array}$ & $\begin{array}{l}89.47 \% \\
10.53 \%\end{array}$ & $\begin{array}{l}170 \\
20\end{array}$ & $\begin{array}{c}1 \\
5.539(2.098-14.624)\end{array}$ & 0.0005 \\
\hline $\begin{array}{l}\text { ASA score } \\
\quad \leq 3 \\
>3\end{array}$ & $\begin{array}{l}17.37 \% \\
82.63 \%\end{array}$ & $\begin{array}{c}33 \\
157\end{array}$ & $\begin{array}{c}1 \\
9.180(1.211-69.590)\end{array}$ & 0.032 \\
\hline $\begin{array}{l}\text { Boey score } \\
\quad \leq 1 \\
\quad>1\end{array}$ & $\begin{array}{l}84.21 \% \\
15.79 \%\end{array}$ & $\begin{array}{c}160 \\
30\end{array}$ & $\begin{array}{c}1 \\
18.000(7.187-45.084)\end{array}$ & $<0.0001$ \\
\hline $\begin{array}{l}\text { PULP score } \\
\quad \leq 7 \\
>7\end{array}$ & $\begin{array}{l}74.21 \% \\
25.79 \%\end{array}$ & $\begin{array}{c}141 \\
49\end{array}$ & $\begin{array}{c}1 \\
18.000(7.473-43.358)\end{array}$ & $<0.0001$ \\
\hline
\end{tabular}

SD: Standard deviation, NSAIDs: Non steroidal anti-Inflammatory drugs, ASA: American Society of Anaesthesiologists, PULP: Peptic ulcer perforation score.

Table 2. Diagnostic ability and performance of ASA, Boey and PULP score for predicting risk of mortality

\begin{tabular}{|l|c|c|c|c|c|c|c|}
\hline \multirow{2}{*}{ Score } & \multicolumn{3}{|c|}{ AUC* } & & \multirow{2}{*}{} \\
\cline { 2 - 7 } & Value & $\mathbf{S E}^{\mathbf{a}}$ & $\mathbf{9 5 \%} \mathbf{C l}^{\mathbf{b}}$ & Sensitivity & Specificity & PPV & NPV \\
\hline ASA & 0.590 & 0.0215 & 0.516 to 0.661 & 97.22 & 20.78 & 12 & 98.5 \\
\hline Boey & 0.745 & 0.0432 & 0.677 to 0.806 & 55.56 & 93.51 & 48.7 & 95 \\
\hline PULP & 0.804 & 0.0392 & 0.740 to 0.858 & 75 & 85.71 & 36.8 & 96.9 \\
\hline
\end{tabular}

AUC: Area under curve, SE: Standard error, Cl: Confidence interval, PPV: Positive predictive value, NPV: Negative predictive value, ASA: American Society of Anaesthesiologists, PULP: Peptic ulcer perforation score.

a Delong et al., 1988.

${ }^{\mathrm{b}}$ Binomial exact.

${ }^{*}$ p value $<0.0001$. 


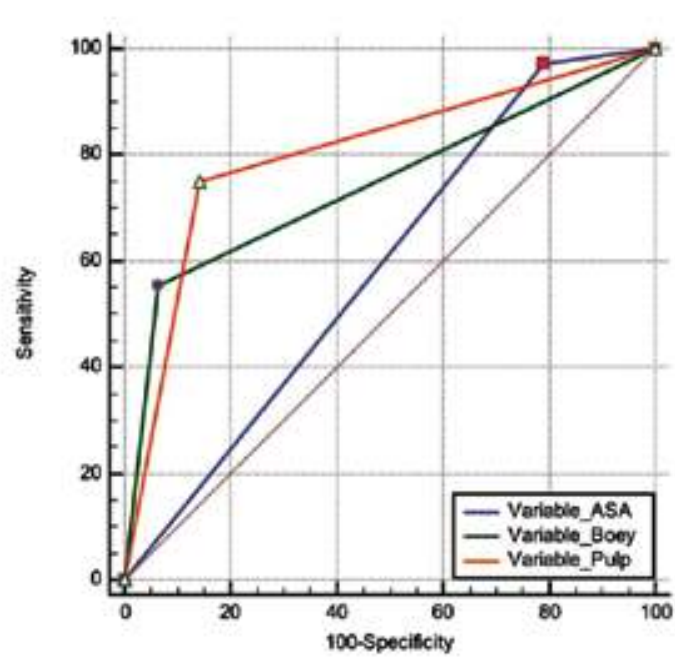

Figure 1. Comparison of ROC curve for ASA, Boey and PULP score.

as including the score in calculations did not change the result significantly.

\section{DISCUSSION}

Prevalence of mortality in our study population (18.95\%) was less as compared to that noted in previous studies on Western populations $(5,6)$, but higher than studies in other Southeast Asian populations $(9,10)$. This may be because of the advanced age of patients presenting with PPU in Western studies (mean age $\sim 70$ years) compared to Asian studies (mean age $~ 50$ years). The elderly, besides suffering from additional pre-operative illnesses such as hypertension and diabetes, have poor physiological reserves to deal with post-operative complications and hence are more prone to fatality.

\section{Demographic Profile and It's Relation to 30-Day Mortality}

Higher rate of PPU was observed in males similar to two other studies $(9,10)$. Another Indian study comprising of 50 perforated peptic ulcer patients noted a very high male to female ratio (11.5:1) and attributed it to the habits of smoking and alcohol consumption in young men (11). The current study did not elicit the habits of smoking and alcohol consumption in our patient population. We recorded PPU more commonly in younger age groups unlike four other studies where the mean age of patients was above 50 years $(6,9,12,13)$. Analogous to our data, an Indian study noted a lower mean patient age (38.1 years) (11). The odds of death were 1.91 times more if the age of patient was more than $60 \mathrm{yrs}$, which confirm the findings that the elderly suffer from more debilitating morbidity and mortality $(6,12)$. No association could be found by us between gender and mortality.

\section{Preoperative Clinical Parameters and Their Relation to 30-Day Mortality}

The rates of long term steroid and NSAIDs ingestion were lower (4.74\% and $8.95 \%)$ in the current study compared to a study by Moller et al (13\% and 41\%) but higher than those noted by Anbalakan et al. $(0.3 \%$ and $1.8 \%)(6,9)$. None of these studies including ours could find an association between chronic steroid/NSAID ingestion and mortality. At our institution, the significantly higher risk of 30-day mortality (Odds ratio $=17.124$ ) in patients with raised serum creatinine levels was in contrast to another study determining serum creatinine level as an independent risk factor for mortality (12). This could be due to the delayed referral of more critical patients to our tertiary care hospital. Increased creatinine level, which is a well-recognized risk factor for mortality in surgical patients, indicates pre-existing renal failure or acute kidney injury due to dehydration or sepsis caused by PPU (14). The proportion of PPU patients presenting with preoperative shock in our study was lower than that observed by two previous studies, however higherrisk of mortalitywas observed in our patients $(6,12)$. The finding of chronic obstructive pulmonary disease (COPD) in 50\% of our cases correlate with the previous studies recording heart disease, COPD and diabetes mellitus as the most common preoperative co-morbidities in patients with PPU $(6,9-11)$. The co-morbidity rate of $17.89 \%$ in the present research was comparable to that reported in a study from Singapore (9), but lower than that in a Western study (6) which observed large number of cases with co-morbid heart disease, active malignant disease or AIDS and other co-morbidities like hyperlipidemia. Mortality depends on multiple clinical factors and co-morbidities, thus explaining the higher fatality observed by us (Odds ratio=3.000).

Table 3. Logistic regression analysis for mortality

\begin{tabular}{|c|c|c|c|c|c|}
\hline \multirow{2}{*}{\multicolumn{2}{|c|}{ Independent Variables }} & \multirow{3}{*}{$\begin{array}{c}\text { Odds Ratio } \\
12.8599\end{array}$} & \multicolumn{2}{|c|}{ 95\% Confidence Interval } & \multirow{3}{*}{$\begin{array}{c}\mathbf{p} \\
<0.0001\end{array}$} \\
\hline & & & \multirow{2}{*}{$\begin{array}{l}\text { Lower } \\
4.8886\end{array}$} & \multirow{2}{*}{$\begin{array}{c}\text { Upper } \\
33.8295\end{array}$} & \\
\hline Pre-operative clinical variables & Serum creatinine $(>1.47 / \leq 1.47 \mathrm{mg} / \mathrm{dL})$ & & & & \\
\hline & Pre-operative shock (Yes/No) & 4.3294 & 1.5199 & 12.3323 & 0.0061 \\
\hline & Time delay (Yes/No) & 3.6957 & 1.1262 & 12.1271 & 0.0311 \\
\hline \multirow[t]{2}{*}{ PPU scores } & Boey score $(>1 / \leq 1)$ & 5.1473 & 1.7347 & 15.2739 & 0.0032 \\
\hline & PULP score $(>7 / \leq 7)$ & 8.5188 & 3.0861 & 23.5150 & $<0.0001$ \\
\hline
\end{tabular}


Table 4. Comparison of mortality risk prediction models in different studies

\begin{tabular}{|c|c|c|c|c|c|c|}
\hline \multirow[b]{2}{*}{ Scores } & \multicolumn{6}{|c|}{ Study } \\
\hline & Present & Anbalakan $^{9}$ & Menekse $^{13}$ & Thorsen $^{12}$ & Moller ${ }^{6}$ & Nichakankitti ${ }^{10}$ \\
\hline \multirow[t]{2}{*}{ Mortality (\%) } & 18.95 & 7.2 & 10.1 & 16.3 & 27 & 3.57 \\
\hline & \multicolumn{6}{|c|}{ AUC } \\
\hline ASA & 0.59 & 0.75 & 0.914 & 0.79 & 0.78 & 0.776 \\
\hline Boey & 0.745 & 0.72 & 0.92 & 0.75 & 0.7 & 0.728 \\
\hline \multirow[t]{2}{*}{ PULP } & 0.804 & 0.75 & 0.955 & 0.79 & 0.83 & 0.784 \\
\hline & \multicolumn{6}{|c|}{ Sensitivity } \\
\hline ASA & 97.22 & 83.3 & - & 85.7 & - & - \\
\hline Boey & 55.56 & 58.3 & - & 64.3 & - & - \\
\hline \multirow[t]{2}{*}{ PULP } & 75 & 62.5 & - & 92.9 & - & - \\
\hline & \multicolumn{6}{|c|}{ Specificity } \\
\hline ASA & 20.78 & 98.1 & - & 66 & - & - \\
\hline Boey & 93.51 & 86.3 & - & 94.4 & - & - \\
\hline \multirow[t]{2}{*}{ PULP } & 85.71 & 87.3 & - & 58.3 & - & - \\
\hline & \multicolumn{6}{|c|}{ PPV } \\
\hline ASA & 12 & 16.4 & - & - & - & - \\
\hline Boey & 48.7 & 25 & - & - & - & - \\
\hline \multirow[t]{2}{*}{ PULP } & 36.8 & 27.8 & - & - & - & - \\
\hline & \multicolumn{6}{|c|}{ NPV } \\
\hline ASA & 98.5 & 98.1 & - & - & - & - \\
\hline Boey & 95 & 96.4 & - & - & - & - \\
\hline PULP & 96.9 & 96.8 & - & - & - & - \\
\hline
\end{tabular}

The Boey score measures 'delay' as the time from perforation to surgery while the PULP score considers it to be the time from perforation to admission based on symptom debut. Alike a previous Norwegian study we defined the time 'delay' as the time interval from admission to surgery, because it would be a better prognosticator as time of hospital admission and surgery are always accurately noted in the case records (12). This would eliminate the recall bias by patient or record bias by hospital. We observed around $10 \%$ cases with delay of $>24 \mathrm{~h}$ while Thorsen et alrecorded around 18\% (12). Research by Buck et al. has shown that it is crucial to reduce the time interval between perforation and operation since each hour adds to the poor prognosis (15). Since there are long travelling distances between our hospital and the rural primary care centres the actual delay would be significantly more than that noted, thus explaining the higher risk of mortality in our patients in contrast to that reported by Thorsen et al. (12).

Logistic regression analysis revealed strong correlation between preoperative clinical variables (raised serum creatinine, preoperative shock and time delay in surgery) and mortality as proven in previous studies $(5,6)$.

\section{Comparison of Risk Assessment Scores and Their Relation to 30-Day Mortality}

We evaluated three commonly used scoring systems for predicting mortality in PPU patients. Comparison of Mortality Risk Prediction Models in different studies is illustrated in Table 4. The risk of mortality in patients with higher ASA ( $>3)$, Boey (>1) and PULP (> 7) scores when individually calculated was greater alike a previous study (12). Logistic regression analysis indicated positive relationship between higher Boey/PULP scores and mortality.

In our study, PULP score achieved the highest OR and AUC values, followed by Boey and ASA scores which can be explained by the inclusion of multiple objective predictors related to patients' current health status and acute disease severity in PULP score as compared to the other two. Thorsen et al. included acute state of patient in ASA scoring, therefore observed equal performance of the ASA and PULP score (12). Unlike their analysis, our ASA grading was based only on pre-existing illnesseshence we noted a poor performance by the ASA score. The efficiency of Boey score predicted by us was analogous to most other studies because of the same three variable system employed by all $(6,9,10,12)$. 
Though ASA score is the easiest to calculate, it was not designed for PPU studies. Prior studies have concluded that ASA Physical Status is an objective scoring system having inter-observer variability and hence prone to observer bias $(12,16)$. If the acute state of the patient is not taken into consideration, it may affect the outcome in terms of mortality (17). Boey scoring system includes only three parameters: co-morbidity, preoperative shock and time from onset of abdominal pain. Therefore it is simpler for clinical application (12). Boey score does not take into consideration other well-established prognostic factors like age, sex concomitant drug intake or renal impairment and that leads to its questionable accuracy in predicting mortality risk $(9,18)$. The original Boey score defines shock as blood pressure $<90 \mathrm{mmHg}$ whereas shock by routine definition is systolic blood pressure of $<$ $100 \mathrm{mmHg}$ and pulse $\geq 100 /$ minute. Hence the score may vary if the data collected donot strictly adhere to the original definitions (14). PULP score incorporates parameters of both ASA and Boey score and can be evaluated preoperatively (14). It includes age which is a recognized risk factor for mortality, therefore is more predictive (13). The shortcoming of PULP score is that it ismore clinically complex andrequires exact time of symptom origin and admission for time delay, so not easy to use.

Variations in patient demographic profiles and study inclusion criteria may bias comparison of the AUC values between different studies. Therefore it is preferable to compare ROC curve analysis and AUC values of studies carried out in similar group of patients (14). The PPU scoring systems found in the literature were validated at different times in different countries on different populations with varied ages. So, further validation is recommended before any particular scoring system can be applied to any one population (14).

\section{Strengths and Limitations of Study}

The sample size was relatively small but adequately powered to show association between pre-operative clinical variables and 30-day mortality. In the present study, time 'delay' was considered as the time interval from admission to surgery, which is clinical feasible to monitor thus avoiding bias and hence a more accurate prognosticator. Due to a small sample sizeno significant association was found between use of steroids or NSAIDS and mortality. Individual factors which have demonstrated proven association with PPU and mortality like smoking, alcohol, H. pylori infection, hypoalbumineamia and hyperbilirubinemia were not studied. Preoperative co-morbidities were not independently evaluated for their relation with mortality.

\section{Meaning of This Study and Implications for Clinicians}

The use of a near-ideal and validated mortality risk prediction score would help clinicians find out the prognosis of a patient postoperatively, optimize perioperative care including intensive care and counsel the family appropriately. The role of a surgeon in identifying and modifying the preoperative risk factors is crucial, which can lead to a better outcome in cases of PPU.
A study validating and determining diagnostic effectiveness of other Mortality Risk Prediction Models (MRPMs) like Hacettepe score, Jabalpur score, Charlson co-morbidity index, Sepsis score, Mannheim Peritonitis Index (MPI), Acute physiology and chronic health evaluation II (APACHE II), Simplified acute physiology score II (SAPS II), Mortality probability models II (MPM II) and Physiological and Operative Severity Score for the enumeration of Mortality and Morbidity physical sub-score (POSSUM-phys score) would guide selection of a comprehensive and suitable scoring system for the Indian population.

\section{CONCLUSION}

In conclusion, this study evaluated a limited number of mortality risk assessment tools used frequently in day to day practice to confirm the importance of mortality risk stratification models in evaluating the prognosis of postoperative patients of PPU. The PULP score, although more complex, predicted mortality risk better than the ASA score and the Boey score. Elderly population, raised serum creatinine, time delay to surgery $>24$ hours, preoperative shock and pre-existing medical illness predictedpoor prognosis. Gender and NSAIDS or steroids intake had no role in mortality risk prediction. A number of scoring systems have been reported yet none prove to be superior and most are tested in isolation on geographically and demographically different study populations. This study confirmed the importance of mortality risk prediction models in assessing the patients of perforated peptic ulcer in Asian-Indian population. A larger study comparing more Mortality Risk Prediction Models would help to identify the risk factors in a wide variety of patients and aid in the improved risk estimation.

Ethics Committee Approval: Approval of the corporate ethics committee was obtained.

Informed Consent: Obtained from all patients.

Peer-review: Externally peer-reviewed.

Author Contributions: Concept - All of authors; Design - All of authors; Supervision - S.K., M.S., D.D.; Resource - S.P., D.K., S.K., D.D.; Materials -S.P., D.K.; Data Collection and/or Processing - S.P., D.K.; Analysis and/or Interpretation - S.P., D.K.; Literature Search - S.P., S.K., D.D.; Writing Manuscript - S.P., S.K., D.D.; Critical Reviews - S.K., D.D.

Conflict of Interest: The authors have no conflicts of interest to declare.

Financial Disclosure: The authors declare that they have no potential conflicts of interest.

\section{REFERENCES}

1. Svanes C. Trends in perforated peptic ulcer: Incidence, etiology, treatment and prognosis. World J Surg 2000;24:277-83. [CrossRef]

2. Aro P, Storskrubb T, Ronkainen J, Bolling-Sternevald E, Engstrand L, Vieth $M$, et al. Peptic ulcer disease in a general adult population. The Kalixanda Study: a random population-based study. Am J Epidemiol 2006;163:1025-34. [CrossRef] 
3. Talley N, Vakil N, Moayyedi P. American gastroenterological association technical review on the evaluation of dyspepsia. Gastroenterology 2005;129:1756-80. [CrossRef]

4. Milosavljevic T, Kostic-Milosavljevic M, Jovanovic I, Krstic M. Complications of peptic ulcer disease. Dig Dis 2011;29:491-3. [CrossRef]

5. Moller MH, Shah K, Bendix J, Jensen AG, Zimmermann-Nielsen E, Ademsen $S$, et al. Risk factors in patients surgically treated for peptic ulcer perforation. Scand J Gastroenterol 2009;44:145-52. [CrossRef]

6. Moller MH, Engebjerg MC, Adamsen S, Bendix J, Thomsen RW. The Peptic Ulcer Perforation (PULP) Score: a predictor of mortality following peptic ulcer perforation. A cohort study. Acta Anaesthesiol Scand 2012;56:655-62. [CrossRef]

7. Dutta AK, Chacko A, Balekuduru A, Sahu MK, Gangadharan SK. Time trends in epidemiology of peptic ulcer disease in India over two decades. Indian J Gastroenterol 2012;31:111-5. [CrossRef]

8. Rosenstock S, Jorgensen T, Bonnevie O, Andersen L. Risk factors for peptic ulcer disease: a population based prospective cohort study comprising 2416 Danish adults. Gut 2003;52:186-93.[CrossRef]

9. Anbalakan K, Chua D, Pandya GJ, Shelat VG. Five year experience in management of perforated peptic ulcer and validation of common mortality risk prediction models - Are existing models sufficient? A retrospective cohort study. Int J Surg 2015;14:38-44. [CrossRef]

10. Nichakankitti N, Athigakunagorn J. The accuracy of prognostic scoring systems for post-operative morbidity and mortality in patients with perforated peptic ulcer. Int Surg J 2016;3:286-90. [CrossRef]
11. Gulzar JS, Paruthy SB, Arya SV. Improving outcome in perforated peptic ulcer emergency surgery by Boey Scoring. Int Surg J 2016;3:2120-8. [CrossRef]

12. Thorsen K, Doreide JA, Soreide K. What is the best predictor of mortality in perforated peptic ulcer disease? A population-based, multivariate regression analysis including tthree clinical scoring systems. $J$ Gastrointest Surg 2014;18:1261-8. [CrossRef]

13. Menekse E, Kocer B, Topcu R, Olmez A, Tez M, Kayaalp C. A practical scoring system to predict mortality in patients with perforated peptic ulcer. World J Emerg Surg 2015;10:7. [CrossRef]

14. Thorsen K, Soreide JA, Soreide K. Scoring systems for outcome prediction in patients with perforated peptic ulcer. Scand J Trauma Resusc Emerg Med 2013;21:25. [CrossRef]

15. Buck DL, Vester-Andersen M, Moller MH. Surgical delay is a critical determinant of survival in perforated peptic ulcer. Br J Surg 2013;100:1045-9. [CrossRef]

16. Mak PH, Campbell RC, Irwin MG; American Society of Anesthesiologists. The ASA Physical Status Classification: inter-observer consistency. Anaesth Intensive Care 2002;30:633-40. [CrossRef]

17. Aronson WL, McAuliffe MS, Miller K. Variability in The American Society of Anesthesiologists Physical Status Classification Scale. AANA Journal 2003;71:265-74. [CrossRef]

18. Moller MH, Ademsen S, Thomsen RW, Moller AM. Preoperative prognostic factors for mortality in peptic ulcer perforation: a systematic review. Scand J Gastroenterol 2010;45:785-805. [CrossRef]

\section{ORIJINAL ÇALIŞMA-ÖZET}

Turk J Surg 2019; 35 (4): 252-258

\section{Perfore peptik ülser hastalığında 30 günlük mortaliteyi öngören prognostik skorlama sistemlerinin geçerliliği}

Shaili Patel, Devanshu Kalra, Samir Kacheriwala, Mihir Shah, Dipesh Duttaroy

Medical College Baroda and Sir Sayajirao Hastanesi, Cerrahi Bölümü, Vadodara, Hindistan

\section{ÖZET}

Giriș ve Amaç: Peptik ülser hastalığında perforasyonların önemli ölçüde morbiditeye ve mortaliteye sebep olduğu bilinmektedir. Bu çalışmanın amaCl, 30 günlük mortaliteyi öngörmede ve risk faktörleri temelinde mortalite risk stratifikasyonunu belirlemede bilinen klinik parametrelerin ve var olan üç skorlama sisteminin etkinliğini karşılaştırmaktır.

Gereç ve Yöntem: Bu çalışma, Batı Hindistan'da 1500 yataklı üçüncü basamak üniversite hastanesinde 14 aylık bir süreç içerisinde perfore peptik ülser sebebiyle opere edilen 190 hastanın prospektif gözlemsel bir çalışmasıdır.

Bulgular: Gözlemlenen mortalite oranı \%18,95 idi. Postoperatif prognozu kötü etkileyen risk faktörleri arasında yaş, yükselmiş serum kreatin seviyesi, ameliyatın 24 saatten daha fazla gecikmesi, preoperatif şok ve var olan tıbbi rahatsızlıklardı. Mortalite öngörmesi için eğri altındaki alan ASA için 0,590 , Boey için 0,745 ve PULP skoru için 0,804 idi. Çok değişkenli regresyon analizi sonucunda mortaliteyi öngören faktörlerin yükselmiş serum kreatin seviyesi, preoperatif şok ve geciken ameliyatlar olduğu belirlendi.

Sonuç: Kötü sonuçlar, yaşlı popülasyonda ve yükselmiş serum kreatin seviyesi olan, peroperatif şok geçiren, önceden tıbbi hastalığı olan ve ameliyata alınmaları 24 saatten daha çok geciken hastalarda belirgin derecede yüksekti. Boey skorlamasının uygulanması daha pratik olsa da PULP skorlama sistemi mortalitenin daha keskin bir göstergesi olarak kanıtlandı. Mortalite Riski Öngörü Modelleri içeren daha geniş bir çalışma daha doğru ve popülasyon spesifik bir skorlama sistemi oluşturmada yardımcı olacaktır.

Anahtar Kelimeler: Perfore peptik ülser, skorlama sistemi, 30 günlük mortalite

Doi: $10.5578 /$ turkjsurg.4211 